\title{
Analisis Persepsi Biaya Kuliah Perguruan Tinggi dengan Menggunakan Metode Regresi Logistik Ordinal
}

\author{
Irvana Arofah \\ Program Studi Matematika, Fakultas Matematika dan Ilmu Pengetahuan Alam, Universitas Pamulang \\ Email: irvanabintang7@gmail.com
}

\begin{abstract}
This study aims to obtain information about the characteristics of students as respondents in this study, knowing the perception of the cost of college education using ordinal logistic regression method. This research was conducted on students of class XII of State High School 8 in South Tangerang City. This sampling is done with simple random (Simple Random Sampling). The sample was 80 students. Data were analyzed using ordinal logistic regression analysis and for real tests the parameters used were likelihood ratio test. Based on the results of the analysis that has been done shows that there are 4 significant variables, namely the study program offered, completeness of the lecture facilities, the quality of tertiary institutions, and the reputation of universities with p-value of $0.043 ; 0.014 ; 0,000 ; 0.001$. Simultaneous testing results show that the model has been significant based on factors that influence the cost of education. Simultaneous testing obtained a decision to reject $\mathrm{H}_{0}$ which means that the coefficient of significant value to the ordinal logistic regression model with a p-value of 0.001 .
\end{abstract}

Keywords: perception, ordinasl logistic regression analysis .

\begin{abstract}
Abstrak
Penelitian ini bertujuan untuk memperoleh informasi tentang karakteristik siswa sebagai responden dalam penelitian ini, mengetahui persepsi biaya pendidikan Perguruan Tinggi dengan menggunakan metode regresi logistik ordinal. Penelitian ini dilakukan pada siswa kelas XII SMU Negeri 8 Kota Tangerang Selatan. Pengambilan sampel ini dilakukan dengan acak sederhana (Simple Random Sampling). Sampel yang diambil berjumlah 80 siswa. Data dianalisis dengan menggunakan analisis regresi logistik ordinal dan untuk uji nyata parameternya menggunakan uji rasio kemungkinan (likelihood ratio test). Berdasarkan hasil analisis yang telah dilakukan menunjukkan bahwa terdapat 4 variabel yang signifikan yaitu Program studi yang ditawarkan, Kelengkapan fasilitas perkuliahan, Kualitas perguruan tinggi, dan Reputasi perguruan tinggi dengan nilai $p$-value masing-masing sebesar 0,043; 0,014; 0,000; 0,001. Hasil pengujian secara serentak menunjukkan bahwa model telah signifikan berdasarkan factor-faktor yang berpengaruh terhadap biaya pendidikan. Pengujian secara serentak diperoleh keputusan tolak $\mathrm{H}_{0}$ yang artinya bahwa koefisien nilai $\beta$ signifikan terhadap model regresi logistik ordinal dengan nilai $p$-value 0,001 .
\end{abstract}

Kata-kata kunci: persepsi, analisis regresi logistik ordinal.

\section{PENDAHULUAN}

Sebagai salah satu wahana pembentuk karakter bangsa, sekolah atau perguruan tinggi adalah lokasi penting dimana para "Nation Builders" Indonesia diharapkan dapat berjuang membawa negara bersaing di kancah global. Seiring dengan derasnya tantangan global, tantangan dunia pendidikan pun menjadi semakin besar. 
Indonesia termasuk negara yang mempunyai tingkat kelahiran yang tinggi di mana generasi muda adalah harapan kita untuk mengembangkan negara ini dan harapannya mereka juga meraih pendidikan setinggi-tingginya. Tapi di era globalisasi telah mengubah cara berpikir masyarakat, yang cenderung meninggalkan budaya ketimuran. Pada saat inilah pendidikan menjadi penting.

Pendidikan merupakan salah satu faktor penting kewibawaan sebuah negara didapatkan. Dengan pendidikan yang baik pastinya akan melahirkan generasi penerus bangsa yang cerdas dan kompeten dalam bidangnya. Sehingga kondisi bangsa akan terus mengalami perbaikan dengan adanya para penerus generasi bangsa yang mumpuni dalam berbagai ilmu.

Perkembangan dunia globalisasi sekarang ini telah membawa pengaruh yang besar dalam sistem pendidikan di Indonesia. Banyaknya tekhnologi yang berkembang sekarang ini seperti internet, teknologi komputerisasi dan sebagainya sangat memudahkan seorang mahasiswa dalam mengembangkan ilmu pengetahuannya. Namun, teknologi yang semakin berkembang tersebut bukanlah jaminan bagi dunia pendidikan untuk berhasil dan mencapai hasil yang maksimal. Hal ini sangat tergantung dari konsistensi dunia pendidikan di Indonesia itu sendiri. Salah satu faktor yang dapat mendukung keberhasilan pendidikan adalah sikap dan mental siswa dalam mengembangkan kemampuannya. Kemampuan siswa untuk mengembangkan minatnya di satu bidang lebih sulit mereka tentukan sendiri karena banyaknya faktor-faktor yang bisa mempengaruhi keputusan mereka.

Di era globalisasi ini, sektor jasa mempunyai peranan sangat penting dan dinamika yang terjadi pada sektor jasa terlihat dari perkembangan berbagai industri jasa, khususnya jasa pendidikan yang kini semakin menyadari perlunya peningkatan orientasi pada pelanggan atau konsumen.

Sektor pendidikan merupakan program utama sebagai pondasi pembangunan bangsa dan negara, sebab pendidikan berupaya mencerdaskan generasi muda menuju terciptanya sumber daya manusia yang cerdas dan berkualitas. Minat melanjutkan studi ke jenjang pendidikan yang lebih tinggi hendaknya selalu dipupuk sejak siswa mulai memasuki sekolah menengah atas karena pada dasarnya minat itu akan tumbuh melalui serangkaian proses.

Pendidikan dalam hal ini perguruan tinggi termasuk dalam kelompok jasa murni (pure service), pemberian jasa yang dilakukan didukung alat kerja atau sarana seperti ruangan kelas, kursi, meja, buku- buku dan lain-lain. Perguruan tinggi sebagai lembaga yang menyelenggarakan pendidikan tinggi tidak lagi menghadapi lingkungan yang stabil, melainkan berada dalam lingkungan yang semakin berubah. Persaingan antar perguruan tinggi menjadi semakin ketat baik mencakup peningkatan jumlah, kualitas, sarana dan prasarana. Semakin ketatnya persaingan di kalangan perguruan tinggi dapat dilihat dengan semakin banyaknya perguruan tinggi yang menawarkan berbagai program pendidikan. Banyak bermunculannya perguruan tinggi, maka konsumen atau calon mahasiswa mempunyai berbagai alternatif pilihan yang sangat banyak dalam menentukan program pendidikan yang sesuai dengan kebutuhan dan harapan mereka.

Sebagai calon mahasiswa, mengetahui informasi tentang kualitas sebuah perguruan tinggi merupakan faktor utama yang digunakan sebagai pertimbangan dalam mengambil keputusan dalam memilih tempat studi. Kualitas suatu perguruan tinggi dapat diukur berdasarkan beberapa aspek seperti : kurikulum yang ditawarkan, profesionelisme pengajar, kelengkapan fasilitas yang dimiliki, masa menunggu pekerjaan, jenjang karier para lulusan, serta metode mengajar dan proses belajar mengajar. Pemasar jasa pendidikan di dunia, menurut Kotler (1996), menawarkan jasa dengan bauran pemasaran yang dikenal dengan 7 P5 : program, price, place (location and deliver system), promotion, process, physical, facilities and people.

Perguruan tinggi merupakan puncak dari proses pendidikan yang ada didunia ini termasuk di Indonesia. Namun, tidak semua masyarakat Indonesia dapat mengenyam pendidikan tinggi. Permasalahan pembiayaan pendidikan di Indonesia masih merupakan tema yang hangat. Penyebab utama dari hal ini adalah tercantumnya persentase biaya pendidikan dalam UUD 1945 yang merupakan hasil amandemen.

Pembiayaan merupakan salah satu aspek yang penting dalam proses penyelengaraan pendidikan baik dari tingkat kementrian pendidikan dan kebudayaan, kementrian agama sampai dengan tingkat satuan pendidikan. Tanpa adanya pengucuran anggaran pendidikan yang lancar dari pemerintah, tentu saja akan sangat berpengaruh terhadap kelancaran penyelanggaraan pendidikan itu sendiri. Maka dari itu pemerintah telah mengatur standar pembiayaan, agar pembiayaan berjalan dengan baik dan lancar. Hal ini temaktub dalam Undang Undang No 20 Tahun 2003, dalam perundang-undang ini kita dapat 
memahami bagaimana seharusnya sekolah melakukan menejemen terhadap anggaran pendidikan yang telah di anggarkan oleh pemerintah melalaui APBN.

Pengorbanan yang diterjemahkan menjadi biaya merupakan faktor yang tidak mungkin diabaikan dalam proses pendidikan. Oleh karena itu dapat diperkirakan bagaimana sulitnya seseorang yang tidak memiliki kemampuan ekonomis untuk akses pada pendidikan yang bermutu.

Berdasarkan latar belakang tersebut penulis merasa tertarik untuk melakukan penelitian mengenai "Analisis Persepsi Biaya Pendidikan Perguruan Tinggi dengan menggunakan Metode Regresi Logistik Ordinal”.

\section{METODE}

\section{Tempat dan Waktu Penelitian}

Penelitian ini dilaksanakan di SMU Negeri 8 Kota Tangerang Selatan mulai bulan Februari 2017.

\section{Teknik Pengambilan Sampel}

Populasi target dalam penelitian ini adalah seluruh siswa yang ada di SMU Negeri 8 Kota Tangerang Selatan pada tahun ajaran 2016/2017. Karena semua anggota populasi mempunyai karakteristik yang sama untuk diteliti, olehnya itu peneliti menetapkan populasi terjangkau dalam penelitian ini adalah Siswa kelas XII.

Kemudian dari populasi terjangkau tersebut diambil sampel sebanyak 3 kelas dari kelas XII. Pengambilan sampel ini dilakukan dengan acak sederhana (Simple Random Sampling). Sampel yang diambil berjumlah 80 siswa.

\section{Teknik Pengumpulan Data}

Data yang digunakan dalam penelitian ini adalah data primer yang diperoleh dari hasil penyebaran kuesioner.

\section{Metodologi Penelitian}

Ada beberapa tahapan yang akan dilakukan pada penelitian ini yaitu sebagai berikut :

1. Tahap Pengumpulan data, terdiri dari:

a. Menentukan rancangan penarikan contoh/sampel

b. Melakukan pengambilan data

2. Tahap Pengolahan data dan analisisnya yang terdiri dari :

a. Melakukan analisis deskriptif terhadap data yang diperoleh dari kuesioner untuk mengetahui gambaran umum tentang responden.

b. Melakukan uji kenormalan terhadap data

c. Melakukan analisis regresi logistik ordinal untuk menentukan persepsi biaya kuliah Perguruan Tinggi.

\section{Teknik Analisis Data}

1. Statistika Deskriptif

Statistika deskriptif adalah suatu metode statistika yang berkaitan dengan pengumpulan dan penyajian suatu gugus data sehingga memberikan informasi yang bermanfaat. Analisis deskriptif meliputi upaya penelusuran dan pengungkapan informasi yang relevan yang terkandung dalam data dan penyajian hasilnya dalam bentuk yang lebih ringkas dan sederhana, yang pada akhirnya mengarah pada keperluan adanya penjelasan (Aunuddin, 1989).

2. Uji Kenormalan Data 
Uji normalitas dilakukan untuk mengetahui apakah sampel yang distribusi normal atau tidak. Uji normalitas yang digunakan yaitu Liliefors pada taraf signifikan $(\alpha=0,05)$. Rumus yang digunakan sebagai berikut:

$$
L o=\left|F\left(Z_{1}\right)-S\left(z_{1}\right)\right|
$$

Keterangan :

$\mathrm{F}(\mathrm{Z} 1)=$ Peluang angka baku

$\mathrm{S}(\mathrm{Z} 1)$ = Proporsi angka baku

Lo = L. Observasi (harga mutlak besar)

3. Analisis Regresi Logistik Ordinal

Analisi Regresi logistik tepat digunakan dalam pembuatan model dimana variabel dependen bersifat kategorikal (nonmetrik) dan variabel dependen boleh bersifat kontinyus ataua kategorikal.

Analisis regresi logistik digunakan untuk melihat hubungan antara peubah respon kualitatif dengan peubah penjelas kualitatif atau kuantitatif. Peubah respon dalam regresi logistik dapat berupa peubah biner maupun nominal atau ordinal.

Pada regresi logistik untuk respon biner, model dibentuk dari fungsi logit peluangnya dengan membandingkan peluang respon jatuh pada kategori pertama terhadap peluang respon jatuh pada kategori kedua. Model logit regresi logistik respon biner didefinisikan sebagai berikut :

$$
\log i t[\pi(x)]=\log \left(\frac{\pi(x)}{1-\pi(x)}\right)=\alpha+\beta x
$$

Regresi logistik ordinal merupakan salah satu analisis regresi yang digunakan untuk menganalisa hubungan antara variabel respon dengan variabel prediktor, dimana variabel respon bersifat polikotomus dengan skala ordinal.

Peluang kumulatif $P\left(Y \leq r \mid x_{i}\right)$ didefiniskan sebagai berikut :

$$
P\left(Y \leq r \mid x_{i}\right)=\pi(x)=\frac{\exp \left(\beta_{0_{r}}+\sum_{k=1}^{p} \beta_{k} x_{i k}\right)}{1+\exp \left(\beta_{0_{r}}+\sum_{k=1}^{p} \beta_{k} x_{i k}\right)}
$$

dimana $x_{i}=\left(x_{i 1}, x_{i 2}, \ldots, x_{i p}\right)$ merupakan nilai pengamatan ke-i $(\mathrm{i}=1,2, \ldots ., \mathrm{n})$ dari setiap variabel prediktor. Pendugaan parameter regresi dilakukan dengan cara menguraikannya menggunakan transformasi logit dari $P\left(Y \leq r \mid x_{i}\right)$ :

$$
\begin{aligned}
& \text { Logit } P\left(Y \leq r \mid x_{i}\right)=\ln \left(\frac{P\left(Y \leq r \mid x_{i}\right)}{1-P\left(Y \leq r \mid x_{i}\right)}\right) \\
& \text { Logit } P\left(Y \leq r \mid x_{i}\right)=\left(\beta_{0_{r}}+\sum_{k=1}^{p} \beta_{k} x_{i k}\right)
\end{aligned}
$$

4. Uji Nyata Parameter

Statistik uji-G adalah uji rasio kemungkinan (likelihood ratio test) yang digunakan untuk menguji peranan peubah bebas dalam model secara bersama-sama (Hosmer \& Lemeshow 1989).

Pengujian secara serentak dilakukan untuk memeriksa kemaknaan $\beta$ terhadap variabel respon secara bersama-sama dengan menggunakan statistik uji.

Hipotesis yang diuji sebagai berikut :

$H_{o}: \beta_{1}=\beta_{2}=\cdots_{. .}=\beta_{p}=0$

$H_{1}$ : paling sedikit ada satu $\beta_{k} \neq 0 ; k=1,2, \ldots, p$

Statistik uji yang digunakan adalah statistik uji $G^{2}$ atau Likelihood Ratio Test.

$$
G=-2 \ln \left[\frac{\left(\frac{n_{0}}{n}\right)^{n_{o}}\left(\frac{n_{1}}{n}\right)^{n_{1}}\left(\frac{n_{2}}{n}\right)^{n_{2}}}{\Pi_{i=1}^{n}\left[\pi_{0}\left(x_{i}\right)^{y_{o i}} \pi_{1}\left(x_{i}\right)^{y_{1 i}} \pi_{2}\left(x_{i}\right)^{y_{2 i}}\right]}\right]
$$

Statistik uji-G mengikuti sebaran $\chi^{2}$ dengan derajat bebas $p$. Hipotesis nol ditolak jika G $>\chi_{(d f, \alpha)}^{2}$. Atau p-value (sig) $<\alpha$.

Pengujian secara parsial dilakukan untuk memeriksa kemaknaan koefisien $\beta$ secara parsial dengan menggunakan statistik uji.

Hipotesis yang diuji sebagai berikut :

$H_{o}: \beta_{k}=0$ 
$H_{1}: \beta_{k} \neq 0 ; k=1,2, \ldots, p$

Statistik uji yang digunakan adalah statistik uji Wald.

$$
W=\frac{\widehat{\beta}_{k}}{S E\left(\widehat{\beta}_{k}\right)}
$$

Daerah penolakan $\mathrm{H}_{0}$ adalah $|\mathrm{W}|>Z_{\alpha / 2}$ atau $W^{2}>\chi_{(\text {(df, } \alpha)}^{2} \quad$ p-value (sig) $<\alpha$.

5. Uji Kesesuaian Model

Pengujian ini dilakukan untuk mengetahui kesesuaian suatu model. tatistik uji yang digunakan adalah statistik uji pearson, dengan hipotesis sebagai berikut.

$\mathrm{H}_{0}$ : model sesuai

$\mathrm{H}_{1}$ : model tidak sesuai

Statistik uji sebagai berikut:

$$
D=-2 \sum_{i=1}^{n}\left[y_{i j} \ln \left(\frac{\hat{\pi}_{i j}}{y_{i j}}\right)+\left(1-y_{i j}\right) \ln \left(\frac{1-\hat{\pi}_{i j}}{1-y_{i j}}\right)\right]
$$

$\hat{\pi}_{i j}=\hat{\pi}_{j\left(x_{i}\right)}$ merupakan peluang obeservasi ke-i pada ke-j. Daerah penolakan H0 adalah jika

$D>\chi_{(d f)}^{2}$, derajat bebas pada uji ini adalah $\mathrm{J}-(\mathrm{k}+1)$ dimana $\mathrm{J}$ adalah jumlah kovariat dan $\mathrm{k}$ adalah jumlah variabel prediktor. Semakin besar nilai deviance atau semakin kecil nilai p-value mengindikasikan bahwa terdapat kemungkinan model tidak sesuai dengan data.

\section{Variabel Penelitian}

Variabel penelitian ini dirangkum dalam tabel berikut :

TABEL 1. VARIABEL PENELITIAN

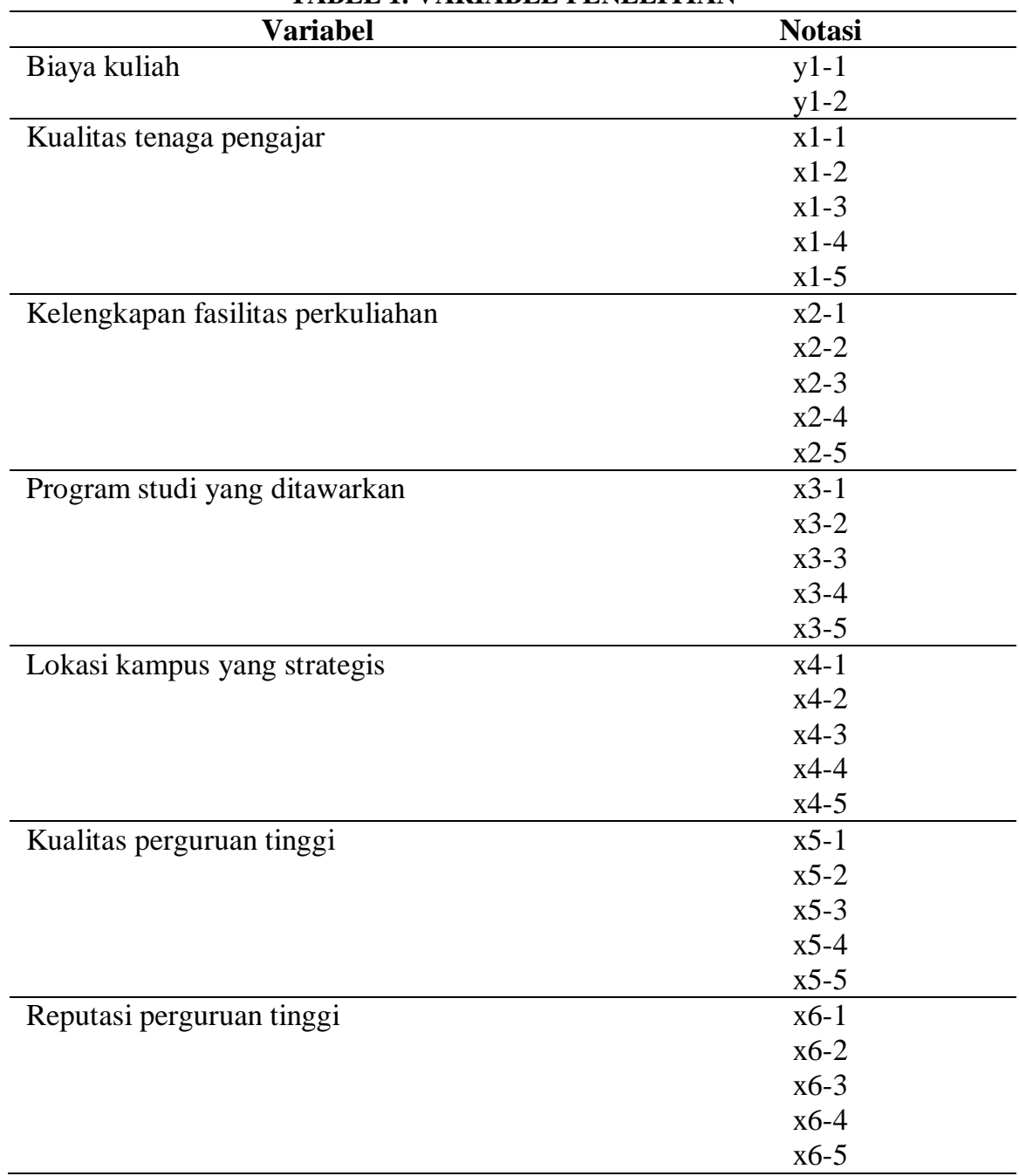




\section{HASIL DAN PEMBAHASAN}

\section{Karakteristik Responden}

Responden dalam penelitian ini terdiri dari 57 \% laki-laki dan 43 \% perempuan. Sebagian besar responden tinggal bersama orang tuanya yaitu sebesar $77 \%$. Sedangkan yang lainnya tinggal bersama famili sebesar $23 \%$. Karakteristik responden berdasarkan keaktifan berorganisasi yaitu sebanyak $62 \%$ siswa aktif berorganisasi dan 38 \% siswa yang tidak aktif berorganisasi.

Gambar 1 menunjukkan bahwa sebagian besar siswa akan melanjutkan pendidikan yaitu sebesar 69 $\%$, sedangkan yang akan bekerja sebesar $26 \%$ dan mengikuti kursus sebesar $5 \%$.

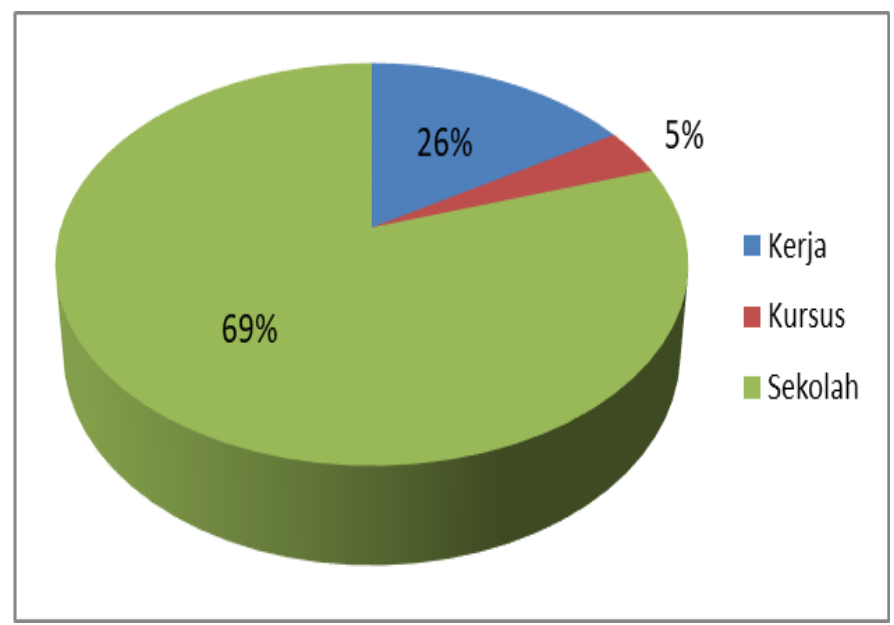

GAMBAR 1. RENCANA SISWA SETELAH LULUS SMA

Persepsi Terhadap Peubah-peubah yang Menjadi Faktor Penunjang Biaya Pendidikan

Pendugaan parameter melalui regresi logistik ordinal untuk mengetahui persepsi biaya pendidikan siswa SMA Negeri 8 Kota Tangerang Selatan.

Berikut disajikan pengujian hipotesis :

TABEL 2. PENDUGA PARAMETER SETIAP PEUBAH

\begin{tabular}{lcc}
\hline \multicolumn{1}{c}{ Peubah Penjelas } & Koefisien & Nilai-p \\
\hline Konstanta ke-1 & -8.050 & 0,000 \\
Konstanta ke-2 & -6.719 & 0,000 \\
Konstanta ke-3 & -5.821 & 0,001 \\
Konstanta ke-4 & -4.784 & 0,006 \\
Tawaran_PS & -0.419 & 0,043 \\
Fasilitas_Lengkap & -0.444 & 0,014 \\
Kualitas_PT & -0.998 & 0,000 \\
Reputasi_PT & -0.622 & 0,001 \\
Kualitas_pengajar & -0.145 & 0,318 \\
Lokasi_strategis & 0.41 & 0,809 \\
\hline
\end{tabular}

Berdasarkan tabeL diatas dapat diketahui variable yang berpengaruh secara signifikan terhadap biaya pendidikan adalah variable-variabel yang memiliki nilai $p$-value $<0,05$. Terdapat 4 variabel yang signifikan yaitu Program studi yang ditawarkan, Kelengkapan fasilitas perkuliahan, Kualitas perguruan tinggi, dan Reputasi perguruan tinggi.

Setelah mengetahui variable-variabel yang berpengaruh maka selanjutkan dibentuk fungsi logit sebagai berikut :

$\mathrm{g}_{1}(\mathrm{x})=-8.050-0.419$ Tawaran_PS -0.444 Fasilitas_lengkap -0.998 Kualitas_PT -0.622 Reputasi_PT 
$\mathrm{g}_{2}(\mathrm{x})=-6.719-0.419$ Tawaran_PS -0.444 Fasilitas_lengkap -0.998 Kualitas_PT -0.622 Reputasi_PT

$\mathrm{g}_{3}(\mathrm{x})=-5.821-0.419$ Tawaran_PS -0.444 Fasilitas_lengkap -0.998 Kualitas_PT -0.622 Reputasi_PT

$\mathrm{g}_{4}(\mathrm{x})=-4.784-0.419$ Tawaran_PS -0.444 Fasilitas_lengkap -0.998 Kualitas_PT -0.622 Reputasi_PT

Pengujian secara serentak juga dilakukan untuk mengetahui apakah model telah signifikan berdasarkan factor-faktor yang berpengaruh terhadap biaya pendidikan. Hasilnya disajikan pada tabel berikut.

TABEL 3. UJI LIKELIHOOD RATIO

\begin{tabular}{lrrrr}
\hline Model & $\mathbf{- 2}$ Log Likelihood & Chi-Square & Df & Sig. \\
\hline Intercept Only & 238.594 & & & \\
Final & 214.663 & 23.931 & 6 & .001 \\
\hline
\end{tabular}

Berdasarkan tabel 3 dapat diketahui bahwa pengujian secara serentak diperoleh keputusan tolak $\mathrm{H}_{0}$ yang artinya bahwa koefisien nilai $\beta$ signifikan terhadap model regresi logistik ordinal.

Pengujian kesesuaian model untuk mengetahui apakah persamaan model yang telah dibentuk sesuai, disajikan pada table berikut.

TABEL 4. UJI KESESUAIAN MODEL

\begin{tabular}{lrrr}
\hline & Chi-Square & df & \multicolumn{1}{l}{ Sig. } \\
\hline Pearson & 316.921 & 166 & .082 \\
Deviance & 211.420 & 166 & .010 \\
\hline
\end{tabular}

Dari tabel 4 dapat disimpulkan bahwa model sesuai atau tidak ada perbedaan yang nyata antara hasil observasi dengan kemungkinan hasil prediksi model karena nilai $p$-value $>0,05$ sehingga disimpulkan $\mathrm{H}_{0}$ ditolak.

\section{Perbandingan Persepsi Peubah-peubah yang Menjadi Faktor Penunjang Biaya Pendidikan}

Perbandingan persepsi setiap peubah dilakukan untuk mengetahui seberapa besar kecenderungan suatu peubah lebih penting dibandingkan dengan peubah lainnya. Perbandingan persepsi setiap peubah dapat diketahui dari perbandingan nilai dugaan rasio oddnya yaitu dengan merasiokan nilai dugaan rasio odd satu peubah tertentu terhadap nilai dugaan rasio odd peubah lain yang ingin diketahui perbandingan prefersninya.

Nilai dugaan rasio odd model regresi logistik ordinal untuk setiap peubah yang menjadi faktor penunjang biaya pendidikan pada siswa SMA Negeri 8 Kota Tangerang Selatan dapat dilihat pada tabel di bawah. Nilai dugaan rasio odd program studi yang ditawarkan sebesar 6,88 menunjukkan bahwa kecenderungan siswa SMA Negeri 8 Kota Tangerang Selatan untuk lebih mementingkan program studi yang ditawarkan adalah 6,88 kali dibandingkan lokasi kampus yang strategis. Sedangkan kecenderungan untuk biaya kuliah sebesar 7,49 kali, kelengkapan fasilitas perkuliahan 7,43 kali, kualitas perguruan tinggi 6,47 kali, reputasi perguruan tinggi 7,95 kali dan kualitas tenaga pengajar 7,38 kali dibandingkan dengan lokasi kampus yang strategis.

TABEL 5. NILAI DUGAAN RASIO ODD MODEL REGRESI LOGISTIK ORDINAL

\begin{tabular}{lc}
\hline \multicolumn{1}{c}{ Peubah Penjelas } & Rasio Odds \\
\hline PS yang ditawarkan & 6,88197 \\
Biaya Kuliah & 7,48938 \\
Fasilitas Lengkap & 7,43344 \\
Kualitas PT & 6,47016 \\
Reputasi PT & 7,95249 \\
Kualitas Pengajar & 7,37811 \\
Lokasi kampus & 1,0000 \\
\hline
\end{tabular}


Jika ingin mengetahui kecenderungan suatu peubah terhadap peubah yang lain maka rasiokan nilai dugaan rasio odd kedua peubah yang diinginkan. Untuk mengetahui seberapa besar kecenderungan siswa SMA Negeri 8 Kota Tangerang Selatan lebih mementingkan kualitas perguruan tinggi dibandingkan kualitas tenaga pengajar maka rasiokan nilai dugaan rasio odd kualitas perguruan tinggi terhadap nilai dugaan rasio odd kualitas tenaga pengajar sehingga dapat diketahui bahwa kecenderungan siswa SMA Negeri 8 Kota Tangerang Selatan untuk lebih mementingkan kualitas perguruan tinggi sebesar 0,88 kali dibandingkan kualitas tenaga pengajar.

Untuk mengetahui seberapa besar kecenderungan siswa SMA Negeri 8 Kota Tangerang Selatan lebih mementingkan biaya kuliah dibandingkan kualitas tenaga pengajar maka rasiokan nilai dugaan rasio odd biaya kuliah terhadap nilai dugaan rasio odd kualitas tenaga pengajar sehingga dapat diketahui bahwa kecenderungan siswa SMA Negeri 8 Kota Tangerang Selatan untuk lebih mementingkan biaya kuliah sebesar 1,02 kali dibandingkan kualitas tenaga pengajar.

Sedangkan kesenderungan siswa SMA Negeri 8 Kota Tangerang Selatan lebih mementingkan reputasi perguruan tinggi dibandingkan kualitas tenaga pengajar maka rasiokan nilai dugaan rasio odd reputasi perguruan tinggi terhadap nilai dugaan rasio odd kualitas tenaga pengajar sehingga dapat diketahui bahwa kecenderungan siswa SMA Negeri 8 Kota Tangerang Selatan untuk lebih mementingkan reputasi perguruan tinggi sebesar 1,08 kali dibandingkan kualitas tenaga pengajar.

\section{KESIMPULAN DAN SARAN}

\section{Kesimpulan}

Berdasarkan hasil analisis yang telah dilakukan menunjukkan bahwa terdapat 4 variabel yang signifikan yaitu Program studi yang ditawarkan, Kelengkapan fasilitas perkuliahan, Kualitas perguruan tinggi, dan Reputasi perguruan tinggi, dengan fungsi logit sebagai berikut :

$\mathrm{g}_{1}(\mathrm{x})=-8.050-0.419$ Tawaran_PS -0.444 Fasilitas_lengkap -0.998 Kualitas_PT -0.622 Reputasi_PT

$\mathrm{g}_{2}(\mathrm{x})=-6.719-0.419$ Tawaran_PS -0.444 Fasilitas_lengkap -0.998 Kualitas_PT -0.622 Reputasi_PT

$\mathrm{g}_{3}(\mathrm{x})=-5.821-0.419$ Tawaran_PS -0.444 Fasilitas_lengkap -0.998 Kualitas_PT -0.622 Reputasi_PT

$\mathrm{g}_{4}(\mathrm{x})=-4.784-0.419$ Tawaran_PS -0.444 Fasilitas_lengkap -0.998 Kualitas_PT -0.622 Reputasi_PT

Hasil pengujian secara serentak menunjukkan bahwa model telah signifikan berdasarkan factorfaktor yang berpengaruh terhadap biaya pendidikan. Pengujian secara serentak diperoleh keputusan tolak $\mathrm{H}_{0}$ yang artinya bahwa koefisien nilai $\beta$ signifikan terhadap model regresi logistik ordinal.

\section{Saran}

Untuk penelitian selanjutnya sebaiknya dilakukan pembandingan antara persepsi biaya pendidikan dari siswa SMA Negeri dengan SMA Swasta. Sehingga jumlah sampel yang diambil harus lebih banyak yaitu dengan memilih beberapa SMA Negeri dan SMA Swasta.

\section{UCAPAN TERIMA KASIH}

Terima kasih kepada semua pihak yang telah membantu baik dalam memberikan saran dan pemberian data dalam menunjang penelitian ini.

\section{REFERENSI}

Arikunto, Suharsimi 1998, Prosedur Penelitian Suatu Pendekatan Praktek, Jakarta: Rineka Cipta. Aunuddin 1989, Analisis Data, Bogor: PAU Ilmu Hayat IPB.

Buzan, Tony, 2003, Head First, Jakarta: Gramedia Pustaka Utama. 
Daniel, W.W 1989, Statistika Non Parametrik Terapan, Terjemahan Alex Tri Kantjono W, Jakarta: PT Gramedia.

Handoko, T. Hani 2001, Dasar-Dasar Manajemen. Yogyakarta: BPFE.

Homes DW, S Lemeshow 1989, Applied Categorical Data Analysis, New York: J.Wiley.

Hurlock, B. Elisabeth 1994, Psikologi Perkembangan, Jakarta: Erlangga.

Kotler, Philip 1997, Manajemen Pemasaran, Jakarta : PT. Prenhallindo.

Dimyati, Mahmud 1990, Psikologi Pendidikan, Depdikbud Jakarta.

Malcolm, Hardy 1988, Pengantar Psikologi, Edisi kedua, Jakarta : Penerbit Erlangga.

Slameto 2003, Belajar dan Faktor-Faktor yang Mempengaruhinya, Jakarta: Rineka Cipta.

Sudjana, Nana 2002, Penilaian Hasil Proses Belajar Mengajar, Bandung: PT. Remaja Rosdakarya .

Sudjana 1996, Metode Statistik, Bandung: Tarsito.

Supranto. J 2004, Analisis Multivariat Arti dan Interpretasi, Jakarta: Rineka Cipta.

Supriadi, Dedi 2004, Satuan Biaya Pendidikan, Jakarta: Remaja Rosda Karya.

Tim Penulis 2003. Analisis Peubah Ganda. Bogor: Departemen Ilmu Statistik IPB.

Walgito, Bimo 2001, Psikologi Sosial: Suatu Pengantar, PT. Andi Offset, Yogyakarta. 